\title{
Morpho-Histological Analysis of Direct Shoot Organogenesis Induced in Flower Buds Cultures of Allium altissimum
}

\author{
Tatyana V. Poluboyarova1, Tatyana I. Novikova1, Galina Yu. Vinogradova², \\ Elena V. Andronova ${ }^{2}$ \\ ${ }^{1}$ Biotechnology Laboratory, Central Siberian Botanical Garden of the Siberian Branch of the Russian Academy \\ of Sciences, Novosibirsk, Russia \\ ${ }^{2}$ Department of Embryology and Reproductive Biology, Komarov Botanical Institute of the Russian Academy \\ of Sciences, St Petersburg, Russia \\ Email: tanita11@mail.ru
}

Received 28 April 2014; revised 27 May 2014; accepted 18 June 2014

Copyright (C) 2014 by authors and Scientific Research Publishing Inc.

This work is licensed under the Creative Commons Attribution International License (CC BY).

http://creativecommons.org/licenses/by/4.0/

c) (7) Open Access

\section{Abstract}

The present work gives a detailed study of in vitro shoot organogenesis of the ornamental onion $A$. altissimum Regel from the buds of the middle layer of the inflorescences. The course of morphogenesis was examined by light and scanning electron microscopy. Histological observation revealed that during 3 - 5 days of culture on the BDS medium supplemented with $2.0 \mathrm{mg} \cdot \mathrm{L}^{-1}$ of BA and $2.0 \mathrm{mg} \cdot \mathrm{L}^{-1}$ of NAA the epidermal cells of the stamen filament in the area of its fusion with the tepal became competent and dedifferentiated. Originally the organogenesis involved several initial epidermal cells. The formation of meristematic centers was observed from day 3 to day 14 . The apical shoot meristems and leaf primordia in a roller shape formed from day 14 to day 28 of culture on the same media. The further development of vegetative shoots and formation of the bulblets were observed when the explants were stimulated by triapenthenol $\left(2.0 \mathrm{mg} \cdot \mathrm{L}^{-1}\right)$.

\section{Keywords}

Allium altissimum, Direct Shoot Organogenesis, Regeneration, Tissue Culture

\section{Introduction}

De novo shoot organogenesis in tissue culture is the key process for both clonal micropropagation and fundamental studies of developmental biology [1] [2]. Studies of genetics, biochemistry, morphology, and cytology 
revealed three basic phases of organogenesis: competence acquisition, cell canalization and determination, and morphogenesis [2]-[4]. The two initial phases are of major interest in terms of developmental biology [5].

Allium altissimum Regel (subgenus Melanocrommyum, genus Allium L.) belongs to the anzur onions (mountain onions), which are endemic for Central Asia and valued as medicinal and food plants. A. altissimum is used as an ornamental plant in landscape design and flower arrangements. Mass propagation of this geophyte is limited by the characteristics of its life cycle: the plants develop slowly from the seeds and reach the generative phase in 6 - 8 years [6]. The vegetative propagation is absent or poorly expressed: during vegetation the mother bulb can form one, rarely two daughter bulblets [7].

Although extensive research has been conducted on clonal micropropagation of the onions, and the majority of the works concern the technology of multiplication of the valuable food cultivars, such as Allium cepa, A. sativum, etc. [8], there is little information on micropropagation of the ornamental species of the subgenus Melanocrommyum [9]-[12].

The use of the subterranean storage organs as the explants is often accompanied by heavy contamination. The methods of regeneration from the floral explants developed for many geophytes allow the researchers to obtain the aseptic culture and conserve the mother plants, which are especially important for propagation of the rare and endemic species [13]. Šušek with the co-authors described an effective method of propagation of Allium giganteum Regel by direct shoot organogenesis omitting the callus stage from the mature flower buds or ovaries [12]. This way of morphogenesis avoids the somaclonal variation caused by chromosomal aberrations and, thus, it is preferred for propagation and conservation of rare genotypes. We have developed the protocol of micropropagation from the flower organs of another anzur species A. altissimum [14]. Our study of morphogenetic potential of the uneven-aged flower buds from the inflorescence of $A$. altissimum has revealed that the best explants are the buds with the style length of $0.4-0.7 \mathrm{~mm}$ that are formed in the middle layer of the inflorescence. The light and scan microscopy showed that the morphogenic tissue in the area of fusion of stamens and tepal possessed the potency for direct shoot regeneration [15]. Present study was undertaken to reveal the characteristics of the initial stages of A. altissimum shoot development in vitro culture from flower buds using morphohistological approaches.

\section{Materials and Methods}

\subsection{Conditions of Culture}

As a source of explants the plants of A. altissimum from the collection of the Herbarium laboratory of the Central Siberian Botanical Garden (Novosibirsk) were used. To establish in vitro culture the inflorescences covered with the spathe were cut 1 - 2 days before opening. This material was surface sterilized for 10 min with $0.2 \%$ mercuric chloride $\left(\mathrm{HgCl}_{2}\right)$ and rinsed with sterile distilled water 3 times.

The details of culture conditions were the same as previously described [14]. To induce the shoots the isolated buds of the middle layer of inflorescence with the style length of $0.4-0.7 \mathrm{~mm}$ were inoculated on the BDS medium [16], supplemented with $3 \%(\mathrm{w} / \mathrm{v})$ sucrose and $2.0 \mathrm{mg} \cdot \mathrm{L}^{-1} \mathrm{BA}$ (6-benzylaminopurine) and $2.0 \mathrm{mg} \cdot \mathrm{L}^{-1}$ NAA ( $\alpha$-naphthaleneacetic acid). After 4 weeks of culture the material was transferred to the same basal medium containing $2.0 \mathrm{mg} \cdot \mathrm{L}^{-1}$ of triapenthenol for shoot development.

The $\mathrm{pH}$ of media was adjusted to 5.5 prior to autoclaving for $20 \mathrm{~min}$ at $120^{\circ} \mathrm{C}$. All cultures were maintained in a growth room at $25^{\circ} \mathrm{C} \pm 1^{\circ} \mathrm{C}$ under a 16-h photoperiod using cool white light $\left(40 \mu \mathrm{mol} \cdot \mathrm{m}^{-2} \cdot \mathrm{s}^{-1}\right)$. The experiment was repeated three times.

\subsection{Histological Studies}

To study the initial stages of organogenesis the buds were fixed for $48 \mathrm{~h}$ in the FAA solution (70\% ethanol, formalin, and glacial acetic acid at the ratio of 100:7:7) every day from day 0 (control) and day 14, then after day 28 of culture on shoot induction media. The permanent preparations were made according to standard cytological procedures [17]. Sections $10-12 \mu \mathrm{m}$ in thickness were obtained using microtome Microm HM 325 (Carl Zeiss), stained with hematoxylin by Ehrlich and Alcian blue and mounted with polyvinyl alcohol "Mowiol" (Fluka, Germany). The prepared slides were studied with the Axioplan 2 imaging (Carl Zeiss) microscope and photographed with the AxioCam MRc5 high-resolution digital camera, using AxioVision 4.8 digital image processing software. 


\subsection{Morphological Studies}

To estimate the morphology of the explants with the newly emerging shoots the stereomicroscopy and scanning electronic microscopy (SEM) were used. The processes of organogenesis were examined during 2 months of cultivation with the Axioscope-40 (Carl Zeiss) stereomicroscope, equipped with the AxioCam MRc-5 using AxioVision 4.8 software. For SEM the fixed material was previously dehydrated in a graded ethanol series and transferred to $100 \%$ acetone, and then to izoamylacetate, after that it was critical point dried and sputter-coated with gold. The morphology of samples was observed using a scanning electron microscope (JSM-6390LASEM, Jeol Co., Japan).

\section{Results}

\subsection{Histological Analysis of the Buds at the Initial Stages of Cultivation (Days 0 - 14)}

By the moment of inoculation to the nutrient media the buds had fully formed elements of the gynoecium, androecium and perianth (Figure 1(a)). In the days 1 - 8 of culture further development of flower buds and

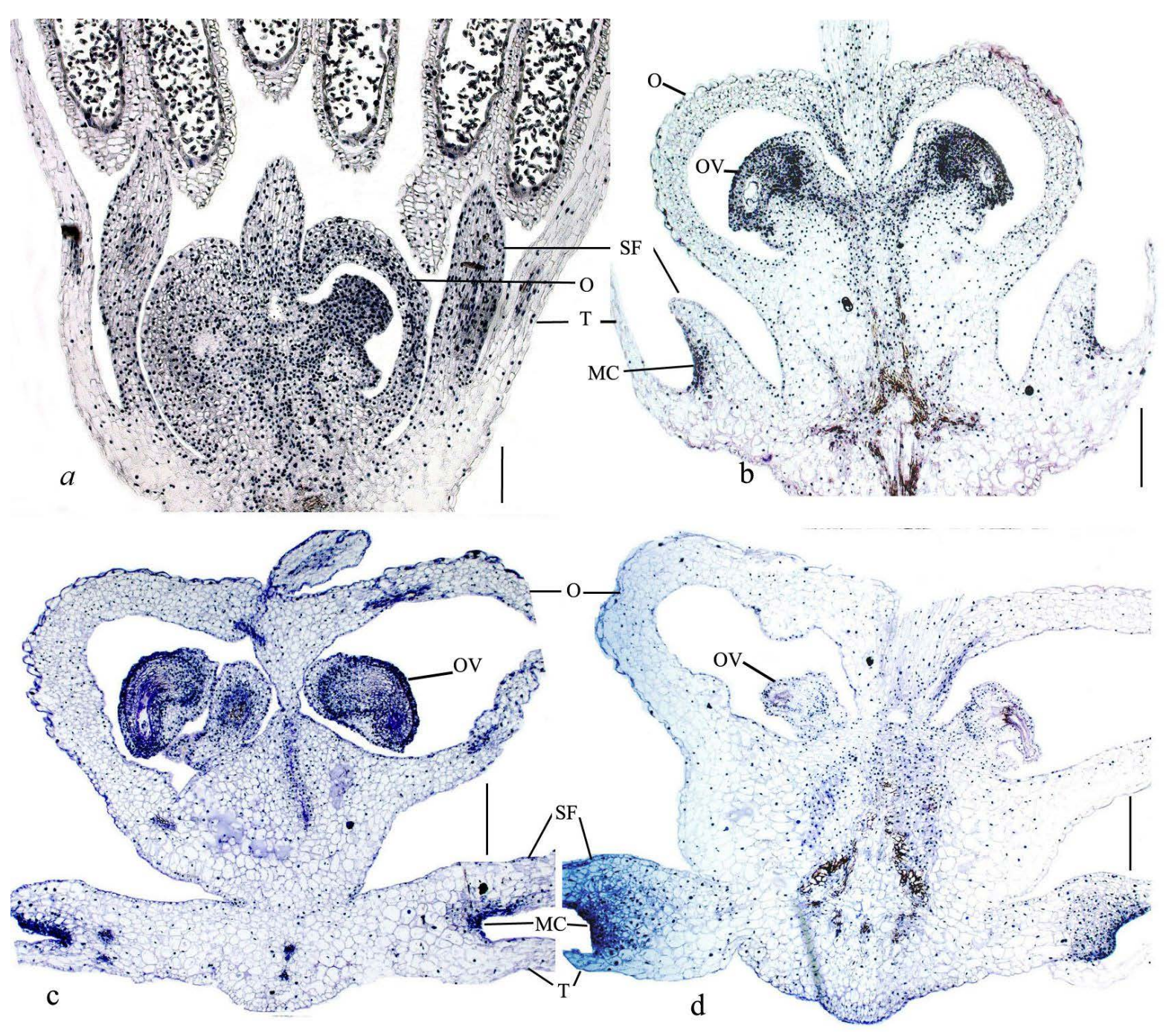

Figure 1. Histological observation of cultured flower buds of A. altissimum: (a) Longitudinal section through a flower bud before culture (day 0, control); (b) Enlargement of flower organs after 5 days of culture; (c) Differentiation of the female gametophyte and their specialization after 8 days; (d) Degeneration of ovules and ovaries after 14days. O, ovary; OV, ovule; T, tepal; MC, meristematic center; SF, stamen filament; Bar represents: a, $0.2 \mathrm{~mm}$; (b)-(d), $0.5 \mathrm{~mm}$. 
increase in size of all organs were observed (Figure 1(b)). During the next week the differentiation of elements of the female gametophyte and their specialization occurred in the ovules (Figure 1(c)). As a result of the lack of fertilization by day 14 the processes of degeneration of the tissues of female reproductive structures-the ovules and, subsequently, the ovaries began (Figure 1(d)). At the same time the meristematic centers formed in the regions of fusion of stamens and tepals (Figure 1(c) and Figure 1(d)).

The detailed histological study showed that the meristematic centers formed as a result of division of epidermal cells of the filament, whereas the epidermis of the tepal did not participate in the process (Figure 2). At the moment of inoculation on the BDS medium (day 0, control) the filament consisted of the epidermal layer and 6 7 layers of parenchymal cells (Figure 2(a)). After the first day of culture on the BDS medium supplemented with BA $2.0 \mathrm{mg} \cdot \mathrm{L}^{-1}$ and NAA $2.0 \mathrm{mg} \cdot \mathrm{L}^{-1}$ the filaments increase in length by the expansion of its cells. However, in the area of the fusions of filament with tepal and filament with the wall of the ovary the cells remained small (Figure 2(b)).

The first cell anticlinal divisions occurred in the epidermis in the fold area between the filament and tepal (Figure 2(b) and Figure 2(c)). By day 3 the number of dividing epidermal cells increased. Vascular bundles were closely located near the area of cell division (Figure 2(d)). On day 5 of cultivation the anticlinal division was joined by periclinal and oblique cell divisions (Figure 2(e)), which later caused formation of subepidermal layers of meristematic centers (Figure 2(f) and Figure 2(g)). On day 11 the number of cell layers in the forming meristem in the fusion area between the filament and tepal increased several times (Figure 2(h)). The tendency for expansion of this centers was observed up to day 14 (Figure 2(i) and Figure 2(j)). As a result of these cell divisions new meristematic centers appeared forming protuberances on the explant surface.

\subsection{In Vitro Regeneration of the Shoots of A. altissimum}

The characteristics of morphogenesis of the shoots were studied by stereo microscopy and SEM. The buds of the middle layer of inflorescence (Figure 3(a)) with the style length of $0.4-0.7 \mathrm{~mm}$ opened on the BDS medium supplemented with BA and NAA $\left(2.0 \mathrm{mg} \cdot \mathrm{L}^{-1}\right)$ in 3 - 5 days after inoculation (Figure 3(b)). After 14 days of culture the tissue proliferation was observed and the first meristematic protuberances appeared (Figure 3(c)). Primordium of the first leaf formed in a shape of a roller occupying a major part of the peripheral area of the shoot apex (Figure 3(d)), which indicated the formation of normal leaf sheaths typical of this species. At this stage of organogenesis the numerous shoots were observed at the different stages of development (Figure 3(e)).

Transferring the explants after 28 days on the BDS medium supplemented with $2.0 \mathrm{mg} \cdot \mathrm{L}^{-1}$ of triapenthenol resulted in the active development of regenerants and intensive growth of their leaves that acquired green color under light and performed assimilative function. The leaf sheaths remained colorless, grew thicker beginning to perform the storage function. As a result of all these processes the small bulblets formed (Figure 3(f)).

\section{Discussion}

Initiation and differentiation of the generative shoots are genetically controlled by the plant, which allows turning the apical meristems of the shoots into meristems of the flower organs [18] [19]. Under the influence of the optimal combination and concentrations of auxins and cytokinins, a reverse process in vitro culture is possible when the primordia of the shoots are formed from the flower organs at a certain stage of their development [13].

This is the first report focused on early stages of shoot organogenesis from flower buds of A. altissimum. The observed histological and morphological events in the formation of the shoots were characterized by certain temporal frames.

Induction of morphogenetic responses was observed rather quickly in epidermal cells in the area of fusion between the filament and tepal. Since the epidermal cells of an intact plant generally divide anticlinally, the periclinal and oblique divisions of these cells indicate the changes in the cells polarity, which might be a signal of the beginning of their dedifferentiation phase [20].

As described here during $3-5$ days of culture the epidermal cells of the filament in the area of its fusion with the tepal became competent, dedifferentiated, and acquired the ability for meristematic activity under the influence of the plant growth regulators. The epidermal cells of this area may be considered to be less determined than others and able to turn into the meristematic cells as a response to the hormonal impact. It should be noted that originally the organogenesis involved several initial cells. Similar reactions of the epidermal and subepidermal cells to the BA impact were demonstrated for the coniferous plants [21] as well as for Begonia rex [22]. 


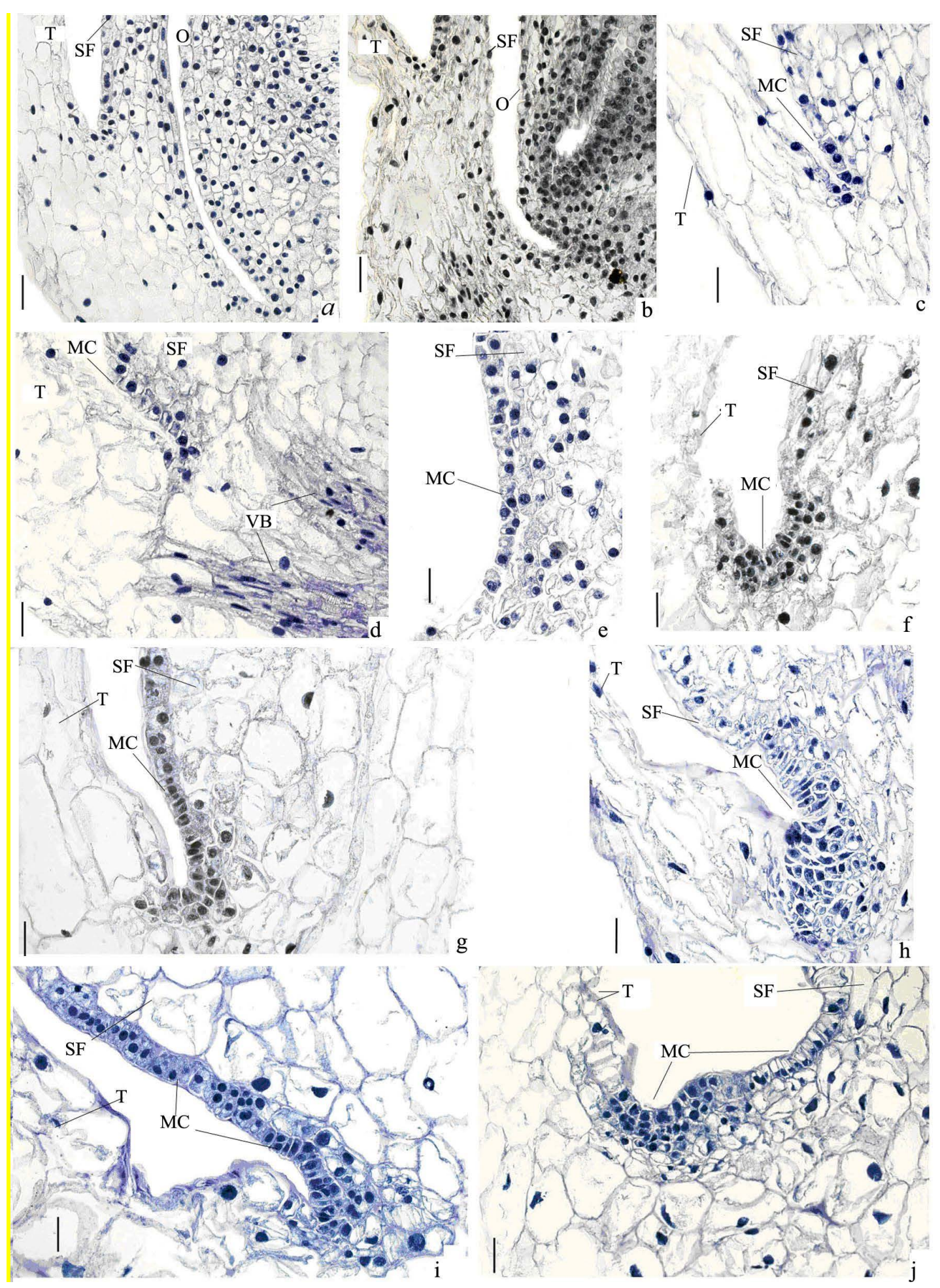

Figure 2. Formation of meristematic centers at the fusion of filament and tepal of A. altissimum flower in response to BA/NAA: (a) Time 0 (control) before culture; (b) Expansion of filament cells after 1 day of culture; (c) First cell anticlinal divisions in epidermis after 2 days; (d) Vascular bundle located in the vicinity of cell divisions area; (e) Anticlinal, periclinal and oblique cell divisions at day 5; (f) Formation of subepidermal layers of meristematic centers by day 8 and (g) day 9; (h) Increase in the number of cell layers by day 11; (i) Meristematic center expansion after 12 days of culture; (j) Small bulge formed after 14 days of culture. O, ovary; T, tepal; MC, meristematic center; VB, vascular bundle; SF, stamen filament; Bar represents: (a)-(j) 0.05 mm. 

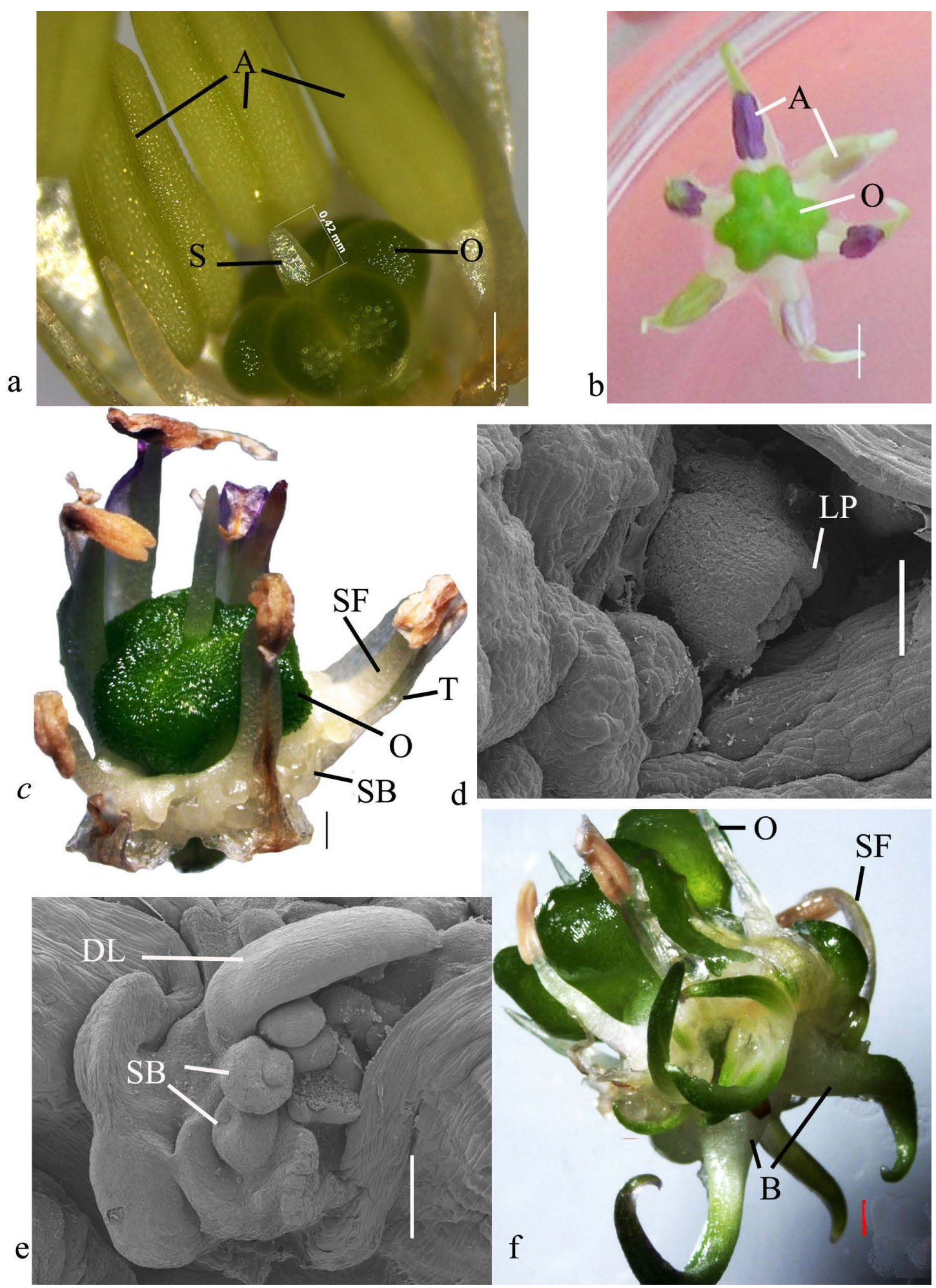

Figure 3. SEM and stereomicroscopy observations of shoot organogenesis of A. altissimum: (a) Flower bud from the middle layer before inoculation; (b) In vitro anthesis at day 3 - 5; (c) Initiation of the shoot buds in the area of the fusion of filaments and tepal; (d) The first leaf primordium; (e) Multiple shoots at different stages of development; (f) The bulblets formation. A, anther; O, ovary; S, style; T, tepal; SF, stamen filament; SB, shoot bud; B, bulblet; LP, leaf primordium; DL, developing leave; Bar represents: (a) 1.0 mm; (b), (f), 1.0 mm; (c), (e), $0.5 \mathrm{~mm}$; (d), $0.2 \mathrm{~mm}$. 
The totipotent nature of the epidermis of Nicotiana tabacum L. with its ability to produce floral buds was revealed by Tran Thanh Van [23].

The formation of the meristematic centers occurred from day 3 to day 14. These centers formed only in the fusion area between the filament and tepal. Between the filament and ovary the epidermal cells were not determinated. The proximity of the vascular bound in the area of the fusion of the filament and tepal could significantly stimulate the meristematic activity of the tissue. These observations on the connection of the cell division and substance inflow through the vascular bounds are confirmed by the data of Sharma and Bhojwani, who studied the differentiation of the shoots from the cotyledons of Brassica juncea (L.) Czern. [24].

The formation of the apical meristems and leaf primordia in the shape of rollers began after 14 days of culture. The further development of the vegetative shoots and formation of the bulblets were stimulated after 28 days of culture with triapenthenol, a plant growth retardant, promoting growth of vigorous shoots. This stage of morphogenesis was observed by SEM and stereomicroscopy.

The present study of morphogenesis from flower buds of the middle layer of A. altissimum in vitro culture revealed that the new organs, shoots, developed from the epidermal layers of the filaments in the area of their fusion with the tepal as a result of direct organogenesis. The data obtained at the initial stages of shoot formation is valuable in terms of developmental biology and can serve as a basis for further biochemical and moleculargenetic studies necessary for revealing the mechanisms that regulate organogenesis in the onions at the molecular level.

\section{Acknowledgements}

This research was supported in part by Project no. 30.3 and no. 30.P of Program Presidium of the Russian Academy of Science "Living nature: state and the problem of development", by Grant President of the Russian Federation for state support of the leading scientific schools (research project No 5282.2014.4), by RFBR research project no. 13-04-96605 a.

\section{References}

[1] Ozawa, S., Yasutani, I., Fukuda, H., Komamine, A. and Sugyama, M. (1998) Organogenic Responses in Tissue Culture of srd Mutants of Arabidopsis thaliana. Development, 125, 135-142.

[2] Duclercq, J., Sangwan-Norreel, B., Catterou, M. and Sangwan, R.S. (2011) De novo Shoot Organogenesis: From Art to Science. Trends in Plant Science, 16, 597-606. http://dx.doi.org/10.1016/j.tplants.2011.08.004

[3] Christianson, M.L. and Warnick, D.A. (1985) Temporal Requirement for Phytohormone Balance in the Control of Organogenesis in Vitro. Developmental Biology, 112, 494-497. http://dx.doi.org/10.1016/0012-1606(85)90423-3

[4] Sugiyama, M. (1999) Organogenesis in Vitro. Current Opinion in Plant Biology, 2, 61-64. http://dx.doi.org/10.1016/S1369-5266(99)80012-0

[5] Schwarz, O., Sharma, A.R. and Beaty, R.M. (2004) Propagation from Nonmeristematic Tissues: Organogenesis. In: Trigiano, R.N. and Gray, D.J., Eds., Plant Development and Biotechnology, CRC Press, Boca Raton, 159-172. http://dx.doi.org/10.1201/9780203506561.ch12

[6] Baitulin, I.O., Rakhimbaev, I.R. and Kamenetskaya, I.I. (1986) Introduction and Morphogenesis of Wild Allium Species in Kazakhstan (In Russian). Nauka, Alma-Ata, 156 P.

[7] Poluboyarova, T.V. and Novikova, T.I. (2011) Biological Peculiarities of Representatives of Subgenus Melanocrommyum in the South-Western Siberia. Vestnik IRGCHA, 44, 102-109.

[8] Gantait, S., Mendal, N. and Das, P.K. (2010) An Overview on in Vitro Culture of Genus Allium. American Journal of Plant Physiology, 5, 325-337. http://dx.doi.org/10.3923/ajpp.2010.325.337

[9] Kamenetskaya, I.I. and Rakhimbaev, I.R. (1984) Vegetative Propagation of Karatavskii Onion in Vitro Culture. Bulletin GBS, 131, 63-65.

[10] Inagaki, N., Matsunaga, H., Kawano, T., Maekawa, S. and Terabun, M. (1992) In Vitro Micropropagation of Allium giganteum R. 1. Callus and Shoot Formation, and Regeneration of Plantlet through in Vitro Culture of Emerged Young Leaves. Science Report of Faculty of Agriculture, 20, 47-53.

[11] Inagaki, N., Matsunaga, H., Kanechi, M. and Maekawa, S. (1994) In Vitro Micropropagation of Allium giganteum R. 2. Embryoid and Plantlet Regeneration through the Anther Culture of Allium giganteum R. Science Report of Faculty of Agriculture, 21, 23-30.

[12] Šušek, A., Javornik, B. and Bohanec, B. (2002) Factors Affecting Direct Organogenesis from Flower Explants of Al- 
lium giganteum. Plant Cell and Tissue Organ Culture, 68, 27-33. http://dx.doi.org/10.1023/A:1012950601175

[13] Ziv, M. and Lilien-Kipnis, H. (2000) Bud Regeneration from Inflorescence Explants for Rapid Propagation of Geophytes in Vitro. Plant Cell Report, 19, 845-850. http://dx.doi.org/10.1007/s002990000204

[14] Poluboyarova, T.V. and Novikova, T.I. (2013) Clonal Micropropagation of Ornamental Onions of Subgenus Melanocrommyum from Flower Organs. Bulletin of the State Nikitsky Botanical Garden, 107, 46-51.

[15] Poluboyarova, T.V., Andronova, E.V., Novikova, T.I. and Vinogradova, G.Yu. (2011) Shoot Regeneration from Floral Tissues of Allium altissimum (Alliaceae) in Vitro Culture. Plant Resources, 47, 33-42.

[16] Dunstan, D.I. and Short, K.C. (1978) Shoot Production from Onion Callus Tissue Culture. Scientia Horticulturae, 9, 99-110. http://dx.doi.org/10.1016/0304-4238(78)90076-6

[17] Pausheva, Z.P. (1988) Plant Cytology Practical Training. Agropromizdat, Moscow.

[18] Fletcher, J.C. (2002) Coordination of Cell Proliferation and Cell Fate Decisions in the Angiosperm Shoot Apical Meristem. BioEssays, 24, 27-37. http://dx.doi.org/10.1002/bies.10020

[19] Flashman, M.A. and Kamenetsky, R. (2006) Florogenesis in Flower Bulbs: Classical and Molecular Approaches. In: Teixeira da Silva, J.A., Ed., Floriculture, Ornamental and Plant Biotechnology, Vol. 1, Global Science Books, Ikenobe, 33-43.

[20] Lo, K.H., Giles, K.L. and Sawhney, V.K. (1997) Histological Changes Associated with Acquisition of Competence for Shoot Regeneration in Leaf Discs of Sainpaulia ionantha x confuse Hybrid (African Violet) Cultured in Vitro. Plant Cell Reports, 16, 421-425.

[21] Villalobos, V.M., Yeung, E.C. and Thorpe, T.A. (1984) Origins of Adventitious Shoots in Excised Radiata Pine Cotyledons Cultured in Vitro. Canadian Journal of Botany, 63, 2172-2176. http://dx.doi.org/10.1139/b85-307

[22] Chlyah, H. and Tran Thanh Van, M. (1974) Histological Changes Epidermal and Subepidermal Cell Layers of Begonia rex Induced to Form De novo Unicellular Hairs, Buds and Roots. Botanical Gazette, 145, 55-59. http://dx.doi.org/10.1086/337426

[23] Tran Thanh Van, M. (1973) In Vitro Control of de Novo Flower, Bud, Root and Callus Differentiation from Excised Epidermal Tissues. Nature, 246, 44-45. http://dx.doi.org/10.1038/246044a0

[24] Sharma, K.K. and Bhojwani, S.S. (1990) Histological Aspects of in Vitro Root and Shoot Differentiation from Cotyledon Explants of Brassica juncea (L.) Czern. Plant Science, 69, 207-214.

http://dx.doi.org/10.1016/0168-9452(90)90119-9 
Scientific Research Publishing (SCIRP) is one of the largest Open Access journal publishers. It is currently publishing more than 200 open access, online, peer-reviewed journals covering a wide range of academic disciplines. SCIRP serves the worldwide academic communities and contributes to the progress and application of science with its publication.

Other selected journals from SCIRP are listed as below. Submit your manuscript to us via either submit@scirp.org or Online Submission Portal.
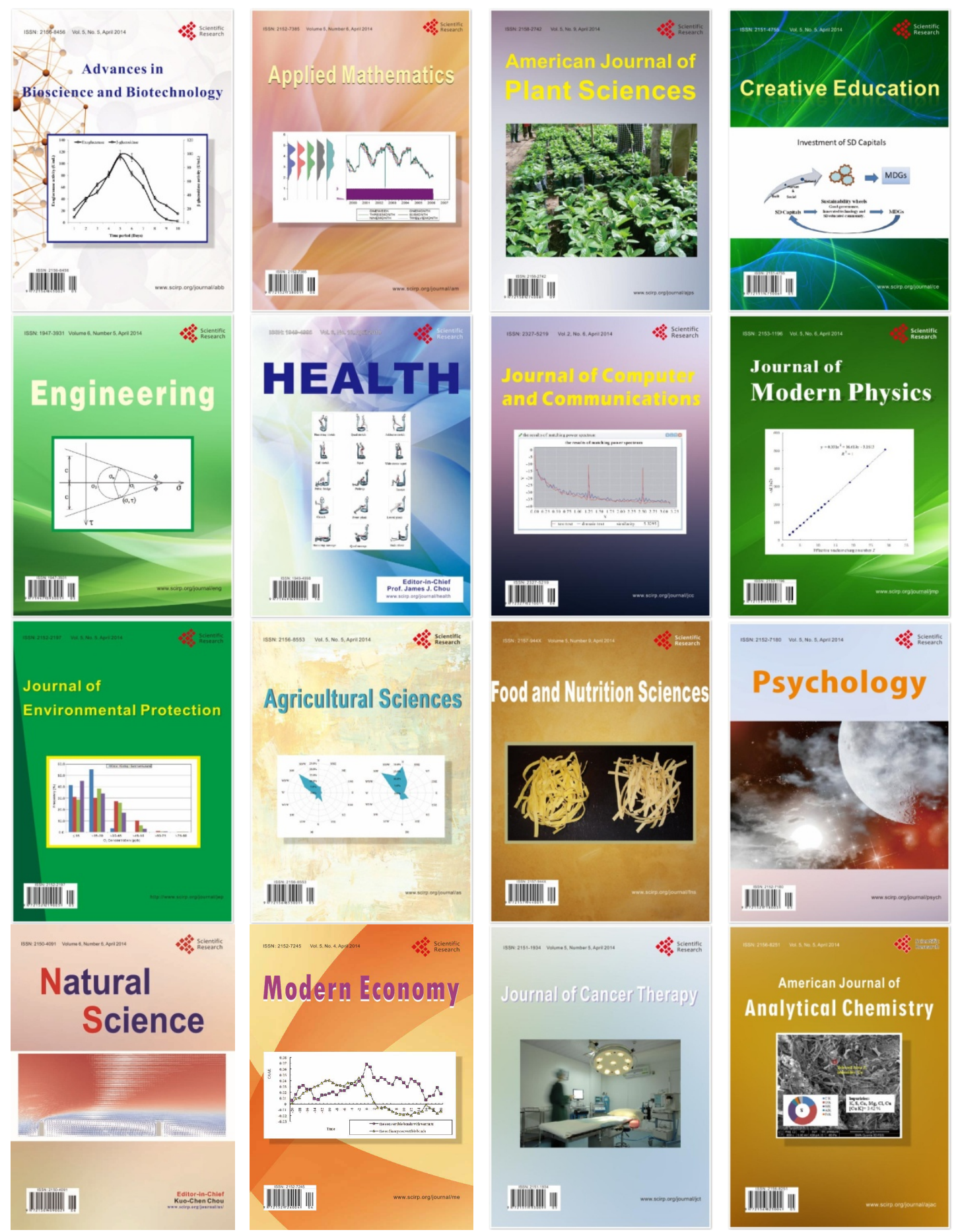